
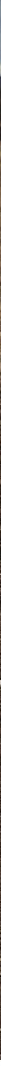
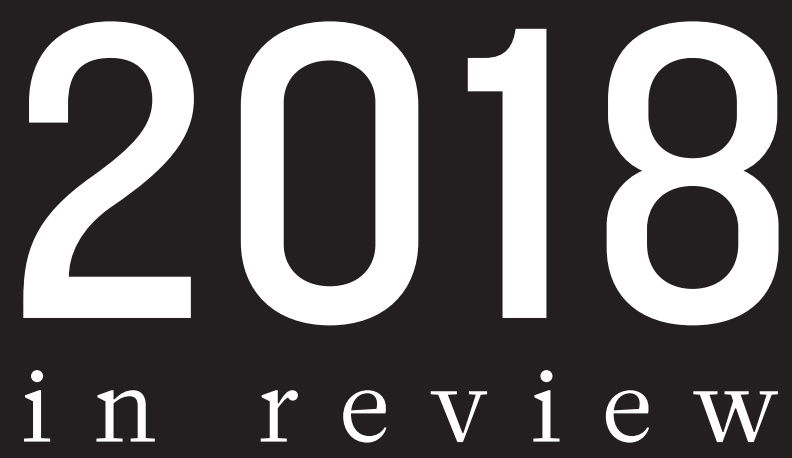

A turbulent year marked by raging

wildfires and allegations of bullying

in the sciences comes to a close.

But researchers can celebrate some

milestones, including the most

accurate map yet of the Milky Way's

stars, and the discovery of bones

showing that a woman who lived

90,000 years ago had a Neanderthal

mother and a Denisovan dad.

\section{UP IN SMOKE}

Evidence of a changing climate continued to mount in 2018. More than 50 fires raged across Sweden in July, fuelled by intense heat and the driest conditions the country had seen in more than a century. By August, British Columbia in Canada was in the middle of its worst fire season on record, and California was battling the largest wildfire in its history. In November, the state faced its deadliest wildfire when the Camp Fire killed at least 85 people.

The situation will probably get worse. The Intergovernmental Panel on Climate Change released a report in October stating that, in as little as a decade, global temperatures could pass $1.5^{\circ} \mathrm{C}$ of warming since pre-industrial times. And there is scant evidence that governments are taking aggressive action to combat global warming.

Australia’s new prime minister, Scott Morrison, abandoned a policy in September that would have limited emissions from the electricity sector, a move that scientists said amounted to abandoning the nation's commitment to the 2015 Paris climate accord.

The US Environmental Protection Agency (EPA) proposed rolling back regulations intended to curb emissions from vehicles and power plants. And in April, then-EPA administrator Scott Pruitt released a proposal that would prevent the agency from basing regulatory decisions on data that aren't publicly available - potentially eliminating epidemiological studies that don't report health data owing to patientprivacy concerns.

On a more positive note, US President Donald Trump, who had gone longer without a top science adviser than any first-term president since at least 1976, finally nominated one in July. But the nominee, meteorologist Kelvin Droegemeier, was still awaiting Senate confirmation as Nature went to press. In China, the government created a ministry of ecological environment to track pollution and enforce environmental rules, as well as an agency to protect endangered species.

There was also movement on two groundbreaking lawsuits that seek to hold governments accountable for their inaction on climate change. 
药 An appeals court in The Hague upheld a 2015 ruling in response to a lawsuit filed by environmentalists that holds the Dutch government responsible for cutting the nation's emissions to 25\% below 1990 levels by 2020 . And the US Supreme Court ruled in November that a case brought in 2015 by 21 young people against the US government can proceed. The plaintiffs argue that the government violated their rights to life, liberty and property by failing to prevent dangerous climate change.

\section{POPULIST UPHEAVAL}

Brazilians elected right-wing candidate Jair Bolsonaro as their next president in October. He has promised to crack down on government corruption - but also to roll back environmental regulations. As a member of Brazil's lower house of Congress, Bolsonaro often voted with the conservative rural caucus, which sought to open up the Amazon rainforest to activities including farming. He takes office in January.

The political upheaval extended to Europe. In Italy, a coalition government comprised of two populist parties took over in June. The recently appointed health minister, physician Giulia Grillo, campaigned to roll back a 2017 decree making multiple vaccinations mandatory for schoolchildren. And in September, she announced that the government would probably continue to make only the measles vaccine compulsory.

In Hungary, Viktor Orbán's populist government announced that it would take control of the Hungarian Academy of Sciences budget, starting in 2019. What that means for scientists working in the academy's 44 research institutes is still unclear. Meanwhile, the Central European University (CEU) in Budapest, an international university founded by billionaire George Soros, was at the centre of a struggle between liberals and the government. An agreement that would allow the CEU to continue to fully operate in the country after the end of the year remains unsigned by the government. The university has announced that it will transfer most of its degree programmes to its Vienna campus in 2019, although research would continue at the Budapest campus.

And as Nature went to press, British Prime Minister Theresa May had just won a 'confidence vote' in her leadership, securing her position as head of the Conservative Party for another year. That vote was triggered by her decision to delay a crucial parliamentary vote on the unpopular Brexit deal hammered out by UK and European Union negotiators. May now hopes to discuss contentious parts of the deal with EU officials, who have insisted that the agreement itself can't be changed. The UK government plans to step up its preparations for the possibility of the country leaving the EU without any deal - a situation that could lead to UK scientists losing access to more than $£ 1$ billion (US $\$ 1.3$ billion) in annual EU research funding, and increased hurdles to the movement of staff, technologies and medicines in and out of the EU.

The political winds shifted in the United States after the country's

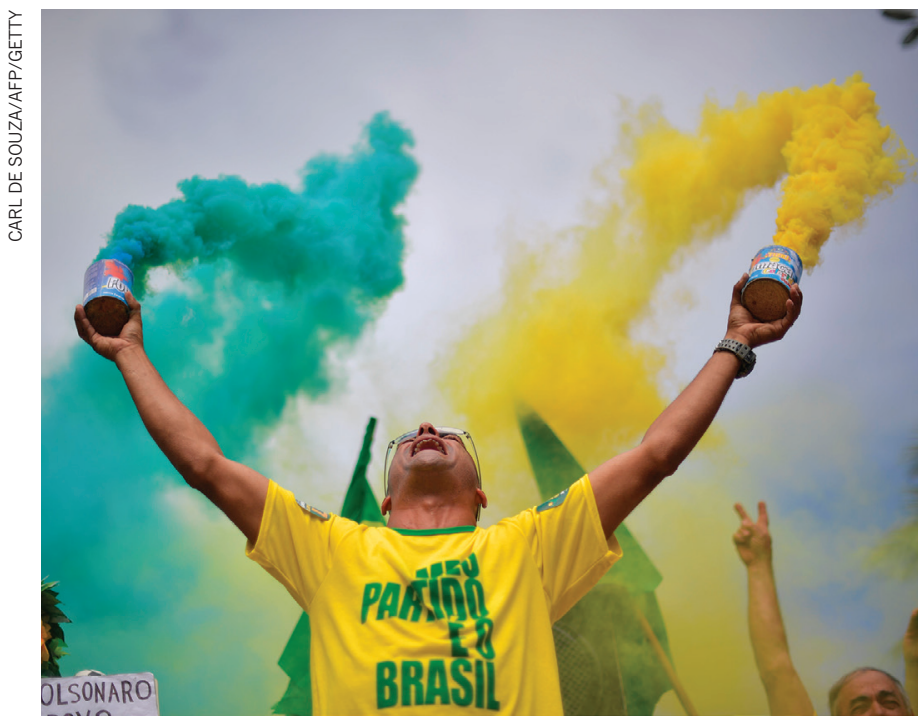

A man shows his support for Brazil's president-elect, Jair Bolsonaro.

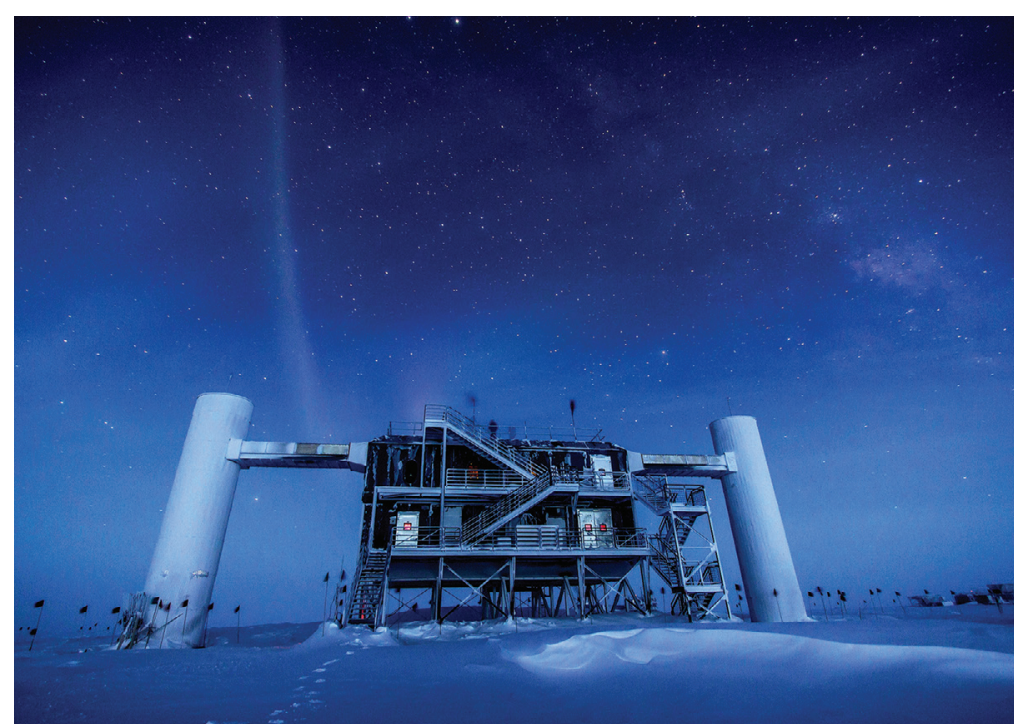

The IceCube observatory recorded data that could be used to track cosmic rays.

November midterm elections. The Democrats regained control of the House of Representatives - but not the Senate - from the Republican Party. The newly elected representatives, including at least 12 with backgrounds in science, technology, engineering or medicine, take office in January. The change will give Democrats control of key committees and the power to subpoena documents and testimony from President Donald Trump's administration. The incoming chair of the House's science panel, Representative Eddie Bernice Johnson (Democrat, Texas), has pledged to investigate the Trump administration, defend science from "political and ideological attacks", and address climate change.

\section{THE RIGHT ANGLE}

Back in the lab, a surprising property of graphene could help to solve a 30-year-old physics mystery. Two layers of the single-atom-thick form of carbon, when sandwiched together and offset by $1.1^{\circ}$, can mimic the superconducting behaviour of some copper-based materials called cuprates. The discovery gives physicists hope that they can use graphene to determine why cuprates conduct electricity without resistance at relatively warm temperatures (see page 325). Graphene is much better understood, and easier to manipulate, than cuprates. The finding, reported in March, could aid in the search for superconductors that don't need to be chilled close to absolute zero.

Superconductor researchers weren't the only physicists having a good year. In October, the European Commission unveiled the first round of winners in its 10-year, $€ 1$-billion (US\$1.1-billion) funding spree for quantum technologies. The 20 projects cover topics such as atomic clocks and secure communications. Meanwhile, the United Kingdom renewed its domestic quantum-hubs programme with an extra $£ 235$ million, and Germany pledged $€ 650$ million for quantum research over 4 years.

The end of the year saw the most significant overhaul of the standard units of measurement since 1875. In November, the General Conference on Weights and Measures in Versailles, France, approved a plan to define all units using fundamental constants of nature, rather than physical reference objects. For example, the kilogram is now rooted in the Planck constant of quantum mechanics rather than in 'Le Grand K', a platinum-alloy cylinder kept in a vault outside Paris.

\section{CONTROVERSIAL EDITS}

The year brought controversial news in the field of genetics. In November, Chinese scientist He Jiankui stunned the world by claiming the birth of the first gene-edited babies. His team used the CRISPR-Cas9 system to alter the CCR5 gene, which encodes a protein that HIV uses to enter cells. The edited embryos produced twin girls, but it is unclear whether the changes will confer resistance 


\section{DECLINING FORTUNES FOR ANIMAL POPULATIONS}

A biennial analysis of land and freshwater animal species, released this year, finds that habitat destruction is one of the most common threats to their populations. Tropical regions were the hardest hit, based on average population sizes in 2014 — the most recent year for which data were available.

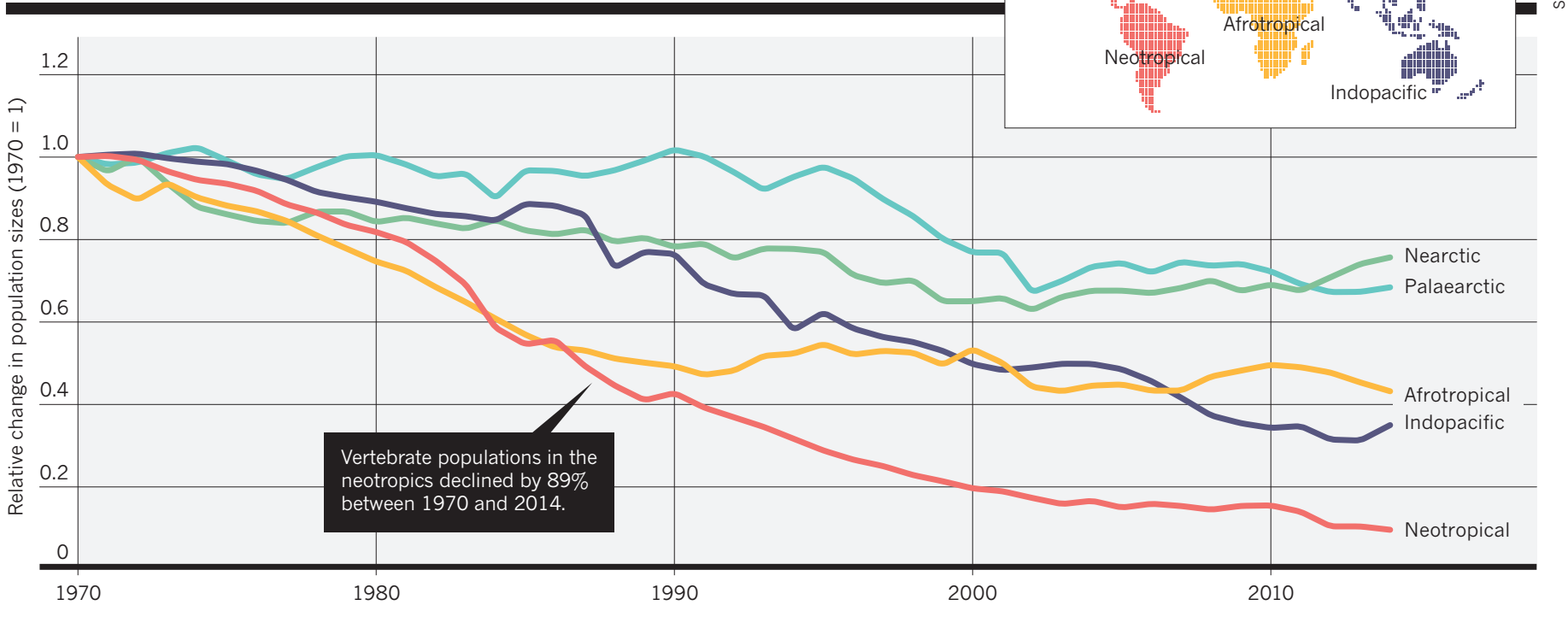

to HIV, especially because one of the babies seems to still have an intact copy of the gene.

Scientists the world over decried the work, warning that the technique is not ready for use in people. As Nature went to press, the Guangdong health commission was investigating $\mathrm{He}$, and China's national science ministry had ordered him to stop doing research.

That announcement capped a year of genetic advances, including the first primates to be cloned using a method similar to the one used to produce Dolly the sheep. The breakthrough, announced in January, could eventually allow researchers to use gene editing to modify primate clones and create models of human disorders.

Another first centred on a young woman who lived some 90,000 years ago. She inherited half of her chromosomes from her Neanderthal mother, and the other half from a Denisovan dad, scientists revealed in August. Dubbed Denny, the hybrid woman is the only known firstgeneration offspring of two distinct hominin groups.

August also saw the approval of the first therapy that relies on a technique called RNA interference to silence a specific gene. It was the culmination of 20 years of dogged pursuit by researchers. The US Food and Drug Administration approved the drug to treat a rare disease called

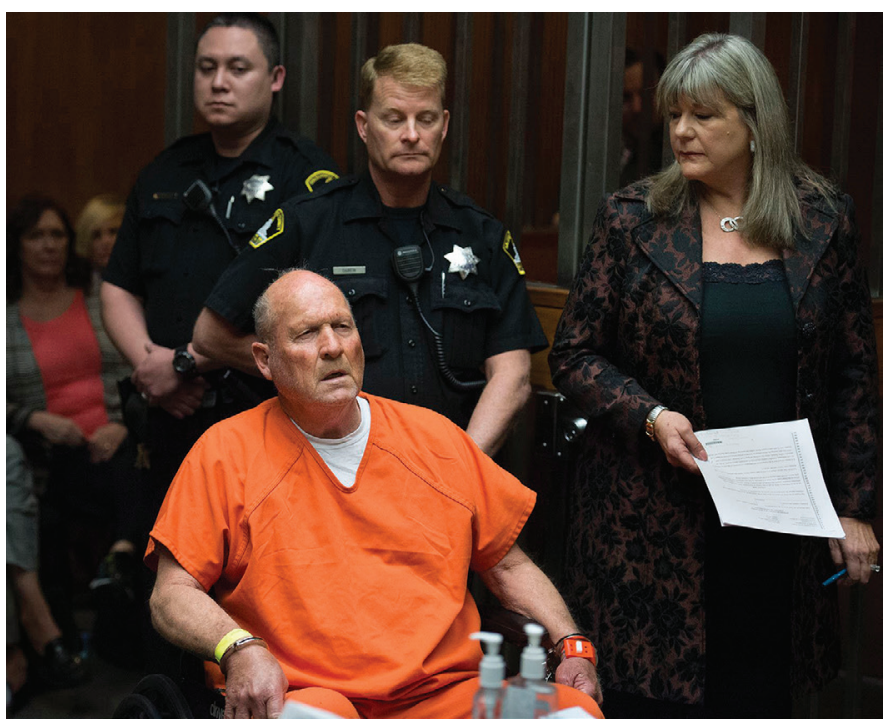

The suspect arrested in California's Golden State Killer case. hereditary transthyretin amyloidosis, which can lead to organ damage.

On the legal front, a fierce patent battle entered its end game in September, when a US federal appeals court upheld patents on CRISPR-Cas9 editing from the Broad Institute of MIT and Harvard in Cambridge, Massachusetts. The fight had pitted the Broad against another team of researchers from institutions including the University of California, Berkeley.

A July ruling by Europe's highest court placed gene-edited crops under the same strict regulations as conventional genetically modified crops: a potential setback for researchers who work on such organisms.

And a surprising turn in a cold case put genetic sleuthing in the spotlight in April. A public genealogy site called GEDmatch enabled an arrest in California's Golden State Killer case. Joseph James DeAngelo is accused of committing a string of murders, sexual assaults and robberies in the 1970s and 1980s. Investigators identified him in part by matching crime-scene DNA to genetic profiles posted by some of his distant relatives on GEDmatch.

\section{BAD BEHAVIOUR}

In the United Kingdom, researchers at several prominent institutes spoke out about bullying, while major science funders cracked down on workplace harassment. In May, the Wellcome Trust in London, a biomedical research funder, introduced a pioneering anti-bullying policy. Three months later, it revoked $£ 3.5$ million from cancer geneticist Nazneen Rahman, who had resigned from the Institute of Cancer Research in London following an investigation into bullying allegations. Rahman said at the time that she and her team would complete their Wellcomefunded research before she left the institute in October.

Later in August, complaints surfaced about the management of the Wellcome Sanger Institute in Hinxton, UK, which is funded by the Wellcome Trust. They included allegations that the institute's director, geneticist Michael Stratton, bullied staff, discriminated against them and misused funds. In October, an investigation reported failings in how people were managed, but cleared senior leaders, including Stratton, of wrongdoing. Stratton apologized for "failures in people management" and the resulting "unintended detrimental effects on individuals". The whistle-blower and some of those who made complaints disputed the investigation's findings.

Bullying was also an issue at the University of Bath, UK, which upheld a complaint against vertebrate palaeontologist Nicholas Longrich, who was part of the team that first discovered a fossilized four-legged snake. After the university's investigation, the Leverhulme Trust in 
